\title{
Knowledge and Export Modes: Which Export Strategy Boosts Firms Knowledge Acquisition?
}

\author{
MARCO DI CINTIO \\ Dipartimento di Scienze dell'Economia \\ Università del Salento*
}

\begin{abstract}
The aim of our research is to investigate whether the choice to export directly versus indirect export plays a role in the level of knowledge acquired by exporting firms. To the best of our knowledge, there is no empirical evidence in this stream of literature and our original contribution consists in considering the outcomes of learning-by-exporting in presence of export intermediaries. Thus, we study whether different export strategies may generate different unobservable productivity premia. In particular, we focused on 25 emerging Countries, and through a machine learning method, we evaluate how the level of knowledge acquired by firms would change if those who chose a specific strategy had instead chosen another one. Our results show that (1) the learning by exporting hypothesis is still valid when firms export indirectly; (2) direct exporters acquire more knowledge than indirect exporters; (3) under the same export strategy, Chinese exporters (direct and indirect) outperform other Asian exporters.
\end{abstract}

Keywords: TFP, Productivity Sorting, Direct and Indirect Trade, Stochastic Dominance, Import - Export.

JEL Classification: D22, F14.

\section{Introduction}

Self-selection and learning-by-exporting are two concepts devoted to explaining different and distinct economic hypothesis. In the last decade, an extensive literature tried to clarify the relationship between firms' productivity and exports. It is true and empirically ascertained that exporters tend to outperform non-exporters, but whether it is productivity to push exports or exports to improve productivity is still under investigation.

\footnotetext{
*Ecotekne via per Monteroni 73100 Lecce, Italy; e-mail: marco.dicintio@unisalento.it
}

Funding information: This project has received funding from the European Union's Horizon 2020 research and innovation programme under the Marie Sklodowska-Curie grant agreement No 734447.

Acknowledgment: I am especially grateful to "Center for Industrial Technology Economy and Management (CITEM)" at the Jinan University - Guangzhou (CHINA), where I conducted this research.

(C) 2020 Mario Di Cintio. Licensed under the Creative Commons Attribution - Noncommercial 4.0 Licence (http://creativecommons.org/licenses/by-nc/4.0/. Available at http: //rofea.org 
On the one hand, under the self-selection hypothesis, it is assumed that more productive firms become exporters. Since additional costs of selling goods abroad represent sunk costs (Bernard and Wagner, 2001), less productive firms could face difficulties in foreign Countries due to the existence of entry barriers associated with fiercer competition in international markets. Therefore, theoretical literature of international trade with heterogeneous firms predicts that only high-productive firms self-select successfully into export markets (Melitz, 2003). Thus, before exporting, firms have to achieve a productivity level high enough (Lachenmaier \& Wößmann, 2006).

However, the direction of causality between productivity and exports can also work in reverse, and it is also possible that the export's involvement makes firms more productive.

Thus, on the other hand, the learning-by-exporting hypothesis considers foreign market as a channel to improve firms' productivity and efficiency. Firms in international markets are exposed to more intense competition, and exporters learn from foreign competitors and buyers. Since Knowledge acquired from foreign markets help exporting firms to improve their performance, this learning-by-exporting hypothesis argues that firms may raise productivity and improve their innovative capacity by competing abroad (Damijan et al., 2010; De Loecker, 2013; Greenaway \& Kneller 2007).

On this last perspective, recent empirical papers used firm level data to investigate the relationship between exporting and firms' productivity. ${ }^{1}$ For instance, Haidar (2012) investigated on the direction of causality between trade and firm productivity by studying Indian manufacturing firm, and he concludes that it is not the case that learning-by-exporting is a channel to enhance Indian firms' productivity. Moreover, in a survey analysis, Wagner (2007) compares methodologies and results of a number of empirical studies performed on different countries. ${ }^{2}$ In particular, his findings seem to conduct in the direction of the selfselection hypothesis rather than that of the learning-by-exporting one. On the other hand, there are many empirical studies that found a positive impact of exports on firms' innovation. Salomon \& Shaver (2005), Golovko \& Valentini (2014) and Damijan \& Kostevc (2015) for Spanish exporters. Gorodnichenko et al. (2010) for exporters in 27 transition economies. Bratti \& Felice (2012) for Italian firms. Olabisi (2017) for Chinese firms.

Nonetheless, it is worth noticing that the learning-by-exporting hypothesis assume implicitly that firms export directly, by ignoring a new stream of recent research that looks at

\footnotetext{
${ }^{1}$ There is also a stream of literature that used aggregate data to investigate the role of exports in promoting Countries' economic growth.

2 Industrialized Country (U.S., UK, Canada, Germany), Latin American Countries (Chile, Colombia, Mexico); Asian countries (China, Korea, Indonesia, Taiwan); Transition Countries (Estonia, Slovenia); Least developed Countries from sub-Saharan Africa.
} 


\section{CINTIO Export Strategy and Firm Knowledge Acquisition}

firms that export indirectly by making use of trade intermediaries (Abel-Koch, 2013; Bernard, Grazzi \& Tomasi, 2015). However, while some efforts have been made to understand how intermediaries facilitate trade (Feenstra \& Hanson, 2004; Antras \& Costinot, 2011), just one handful of studies investigates on the relationship between firm's characteristics and strategies (or modes) of exporting.

Among these few studies, Abel-Koch (2011) shows that in Turkey there is a negative correlation between firm size and the relative prominence of indirect exports as opposed to direct exports. McCann (2013) provides evidence on the existence of the productivity ranking among direct exporters, indirect exporters and non-exporters firms from Eastern European countries. Furthermore, by focusing on a sample of firms in 29 developing economies, Lu et al. (2017) offer a theoretical and empirical analysis of exporting behaviour in the presence of export intermediaries and firms productivity heterogeneity. In particular, they found that - with the increase in productivity - firms switch from to be non-exporter to exporting through intermediaries, and from export indirectly to export directly. Nevertheless, since the above findings are consistent just with the theoretical prediction of the self-selection hypothesis, a reverse fundamental question remains unanswered. Is the learning-by-exporting hypothesis still valid when firms make use of trade intermediaries?

With indirect exports, the trade intermediary acts as a barrier reducing the knowledge transfer between exporting firms and foreign markets, and by potentially lowering their productivity improving. Differently, the knowledge gained by direct exporters regarding products abroad, competing goods and foreign local markets could be potentially higher. Hence, one may postulate intuitively that learning-by-exports is perhaps shrunk when exporting indirectly. Though, to the best of our knowledge, there is no empirical evidence on the impact of export modes on firms' knowledge acquisition. ${ }^{3}$ Therefore, our paper tries to fill in this gap by offering an investigation on whether the firms choice to directly versus indirectly export plays a role in the level of knowledge they may acquire from abroad.

In particular, since firm's knowledge can be viewed as the unobserved firm-specific ability in production (i.e. an unobservable input factor), we proxy the total know-how incorporated in each firm by estimating their Total Factor Productivity (TFP). Hence, our original contribution mainly consists in considering - on the production side - the outcomes of learning-by-exporting

\footnotetext{
${ }^{3}$ A partial exception is due to Di Cintio et al. (2020), who show that - on the demand side - direct exporters are more likely to introduce product innovations compared to non-exporter firms and indirect exporters.
} 
in the presence of trade intermediaries. Specifically, we use firm-level data of 25 emerging Countries $^{4}$ to answer two main research questions:

1) Is the learning-by-exporting hypothesis still valid when firms export indirectly?

2) Do direct exporters acquire more knowledge than indirect exporters?

Moreover, since China has grown to be the world largest exporter among developing economies, it is among the more excellent candidate for this study. For instance, Chinese exporters (in 2005) feature in $85 \%$ of U.S. imported manufactured goods categories (Schott 2008). Therefore, in considering exporting as a potential driver of knowledge acquisition, our analysis also tries to shed light to what extend the learning-by-exporting may explain the larger growth of Chinese firms with respect other Asian firms in the international scenario.

Hence, given the importance of international knowledge transfer to firms' growth, this study also provides a novel comparison among Chinese and other Asian firms, by asking:

3) whether Chinese exporters had acquired more or less knowledge than other Asian exporters.

The remainder of this paper is structured as follows. Section 2 describes the data, provides a brief background of the methodological approach and illustrates our empirical strategy. Results are presented in Section 3. Specifically, Section 3.1 provides a graphical analysis of TFP distributions under different export strategies and reports the results of tests of first-order stochastic dominance. By estimating the propensity score through a machine learning method, results based on the Average Treatment effect on the Treated (ATT) are presented in Section 3.2. Finally, Section 3.3 compares Chinese firms and other Asian firms. Section 4 concludes the paper.

\section{Data and Empirical Strategy}

\subsection{Data Description}

Our empirical study draws on data from the WBES (World Bank Enterprise Surveys), detailed firm-level data collected by the World Bank. In each country under investigation, surveys were collected under a common global sampling methodology. The sample was stratified by sector, size, and geographical region. Country data are currently available for 148 economies and more than 168,000 firms. Specifically, the data are provided in two different schemes. The first

\footnotetext{
${ }^{4}$ Bangladesh, Benin, Brazil, Chile, China, Ecuador, Egypt, Arab Rep., El Salvador, Ethiopia, Guatemala, Guyana, Honduras, India, Indonesia, Madagascar, Malawi, Mauritius, Nicaragua, Pakistan, South Africa, Sri Lanka, Tanzania, Thailand, Turkey, Vietnam.
} 


\section{CINTIO Export Strategy and Firm Knowledge Acquisition}

scheme refers to country-specific surveys, which provide the broader survey information for each country. Differently, the second format (the standardized-comprehensive survey) furnishes data matched among countries for a standard set of questions. We prefer to use the "Standardized data 2002-2006" because it contains some time-series aspects about firms accounting balance sheets and permits also a cross-Country analysis. ${ }^{5}$ In particular, data initially contained 71,789 firms from 104 Countries over the period 2002-2006.

We identify four categories of firms for the purposes of our research. Specifically, we distinguish three different export modes and consider non-exporters as a separate category with respect to firms actually involved in export activities. In particular, firms were asked to report the percentage of establishment's sales sold domestically, through indirect export and through direct export. Thus, firms are non-exporter if they had sales only in the domestic market. Differently, while firms are direct exporters if they had a positive share of sales in the form of direct exports, firms are indirect exporters if they had a positive share of sales in the form of indirect exports. With respect to firms who reported positive shares of sales in the forms of both direct and indirect exports, we code these firms as mixed exporters.

Once we removed firms reporting missing values in accounting balance sheet data and export modes, we left with 11,378 firms coming from 25 countries. Among them, firms come from 8 South American countries (Brazil, Chile, Ecuador, El Salvador, Guatemala, Guayana, Honduras, Nicaragua) 8 African countries (Benin, Egypt, Ethiopia, Madagascar, Malawi, Mauritius, South Africa, Tanzania), 8 Asian Countries (Bangladesh, China, India, Indonesia, Pakistan, Sri Lanka, Thailand, Vietnam) and 1 European country (Turkey). Table 1 reports more detailed country data and export modes statistics.

Before we present the estimation results, in Table 2 we provide some initial evaluation of the above four categories of firms in terms of output (sales) and observable input factors (number of workers and level of capital). ${ }^{6}$ Along each of these indicators, direct exporters have, on average, the highest mean value, followed by mixed exporters, then indirect exporters and finally non-exporters. What about the level of Knowledge (the unobservable input factor) incorporated in each firm? To answer this question, we proxy the firms' knowledge by estimating their Total Factor Productivity (TFP).

\footnotetext{
${ }^{5}$ Time-series information is fundamental to obtain unbiased estimations of firms TFP. However, WBES is a cross-sectional data with limited time-series aspects.

${ }^{6}$ Since monetary variables are in local currency units and span on different fiscal years, all data were converted into U.S. Dollars using the official exchange rate and they were deflated to 2009 using the GDP deflator for the United States.
} 
Review of Economic Analysis 12 (2020) 461-483

Table 1: Country Data and Export Modes Statistics

\begin{tabular}{|c|c|c|c|c|c|}
\hline Countries & Freq. & Percent & Export Mode & Freq. & Percent \\
\hline Bangladesh & 61 & 0.54 & Non-exporter firms & 7,518 & 66.07 \\
\hline Benin & 119 & 1.05 & Indirect Exporters & 597 & 5.25 \\
\hline Brazil & 1492 & 13.11 & Mixed Exporters & 463 & 4.07 \\
\hline Chile & 914 & 8.03 & Direct Exporters & 2,800 & 24.61 \\
\hline China & 537 & 4.72 & Total & 11,378 & 100.00 \\
\hline Ecuador & 233 & 2.05 & & & \\
\hline Egypt, Arab Rep. & 437 & 3.84 & & & \\
\hline El Salvador & 325 & 2.86 & & & \\
\hline Ethiopia & 191 & 1.68 & & & \\
\hline Guatemala & 374 & 3.29 & & & \\
\hline Guyana & 109 & 0.96 & & & \\
\hline Honduras & 302 & 2.65 & & & \\
\hline India & 1209 & 10.63 & & & \\
\hline Indonesia & 434 & 3.81 & & & \\
\hline Madagascar & 95 & 0.83 & & & \\
\hline Malawi & 132 & 1.16 & & & \\
\hline Mauritius & 59 & 0.52 & & & \\
\hline Nicaragua & 299 & 2.63 & & & \\
\hline Pakistan & 744 & 6.54 & & & \\
\hline South Africa & 477 & 4.19 & & & \\
\hline Sri Lanka & 188 & 1.65 & & & \\
\hline Tanzania & 14 & 0.12 & & & \\
\hline Thailand & 1165 & 10.24 & & & \\
\hline Turkey & 506 & 4.45 & & & \\
\hline Vietnam & 962 & 8.45 & & & \\
\hline Total & 11378 & 100.00 & & & \\
\hline
\end{tabular}


DI CINTIO Export Strategy and Firm Knowledge Acquisition

Table 2: Output and Input factors by Export Mode

\begin{tabular}{|c|c|c|c|}
\hline Export Mode & Variable & Mean & Std. Dev. \\
\hline \multirow[t]{3}{*}{ Non-exporter firms } & Sales (Log) & 10.966 & 2.761 \\
\hline & Workers (Log) & 3.426 & 1.291 \\
\hline & Capital (Log) & 10.391 & 3.065 \\
\hline \multirow[t]{3}{*}{ Indirect Exporters } & Sales (Log) & 11.606 & 2.285 \\
\hline & Workers (Log) & 4.378 & 1.534 \\
\hline & Capital (Log) & 10.899 & 2.789 \\
\hline \multirow[t]{3}{*}{ Mixed Exporters } & Sales (Log) & 12.843 & 2.156 \\
\hline & Workers (Log) & 4.944 & 1.459 \\
\hline & Capital (Log) & 12.158 & 2.383 \\
\hline \multirow[t]{3}{*}{ Direct Exporters } & Sales (Log) & 12.910 & 2.144 \\
\hline & Workers (Log) & 5.015 & 1.428 \\
\hline & Capital (Log) & 12.241 & 2.386 \\
\hline
\end{tabular}

In particular, we follow the Levinsohn and Petrin (2003) methodology. ${ }^{7}$ For robustness check, we also refer to two alternative estimation methods, that are the Wooldridge (2009) approach and the fixed-effect estimation. ${ }^{8}$

\subsection{Methodological background}

In order to evaluate possible differences in terms of knowledge acquired by firms, we initially implemented the non-parametric one-tailed Kolmogorov-Smirnov (K-S) tests of first-order Stochastic Dominance (SD) among the distributions of TFP of the above four categories of firms. Then, to provide a causal interpretation of such differences, we relied on matching techniques developed in the Potential Outcome literature. In particular, we assume that firms exposed to different treatments (i.e. different export modes) will acquire different levels of knowledge. Therefore, by estimating the impact of export modes on firms' TFP, we will

7 The variables (in logs) used to estimate the gross output measure of the TFP include firms' annual sales as a proxy of output (Y); the number of skilled and unskilled workers as a proxy of labor inputs (L); and the net value of machinery, vehicles, and equipment as a proxy of capital inputs $(\mathrm{K})$. As is standard in the literature, we use the cost of raw and intermediate materials $(\mathrm{M})$ in a control function to account for unobserved productivity shocks.

8 Since the method of Olley and Pakes (1996) treats the endogeneity problem by making use of firms' investment as a proxy for unobservable productivity shocks, the absence of information regarding firms' investments precludes the application of this alternative methodology. 
measure how their TFP would change if firms with a given trade strategy had chosen a different one.

Although a detailed discussion on the methodology and applications of SD tests is beyond the scope of this work, in this section we provide a brief literature review before going on to outline our empirical strategy.

SD theory is useful in many areas of economics. Applications vary from portfolio selection problems (Hanoch and Levy, 1969) to welfare economics (Atkinson, 1987). For instance, it has been successfully employed in various economic fields, such as the theory of labor supply under uncertainty (Lehmann et al., 1981), the theory of the firm under demand uncertainty (Leland, 1972), auction theory (Luo, 2020) and oligopoly theory (Asplund, 2002).

Even though SD techniques have been mainly used in poverty analyses, the SD approach is widely employed also in several different areas ranging from agriculture (Lee et al., 1987) to medicine (Stinnett and Mullahy, 1998). However, due to space constraints, we will review just a few of the main remarks and applications.

The reasons why the SD approach has received growing interest over the years consist of several advantages. First, it is non-parametric, so it is valid under relatively general assumptions and avoids any explicit functional form requirements. Second, it is more general than the meanvariance analysis. Hence, this methodological approach compares the entire distribution rather than simply comparing common means. Third, from a practical point of view, the SD notion translates the concept of "being larger" in a simple binary relation. Given these attractive properties, the SD analysis permits a preliminary screening of investment alternatives. For instance, it provides a proper tool for comparing income distributions. Furthermore, this technique allows the identification of any heterogeneity in the relationship between exporting and the level of productivity.

Moreover, even though SD is traditionally tested pairwise, Kuosmanen (2004) and Post (2003) have recently extended the notion of SD to the case where full diversification is allowed. Thus, inspired by the study of Barrett and Donald (2003), Scaillet and Topaloglou (2010) rely on weighted Kolmogorov-Smirnov statistics in testing for SD efficiency of a given portfolio with respect to all possible portfolios constructed from a set of assets. Furthermore, the subsampling (bootstrap) approach developed by Linton et al. (2005) allow for serial and cross dependence between investment portfolios. Indeed, Gonzalo (2014) applied these tests to determine investment efficiency between U.S. industry portfolios conditional on the dynamics of the market portfolio. Following the same methodology, Pinar et al. (2013) employ the SD analysis to examine whether there has been a general improvement in the official Human Development Index over time. Moreover, they conduct a SD efficiency analysis of the official United Nations' Index as a composite index. In particular, the authors suggest to weighting education more strongly than does the official index, which actually evaluates the three classical dimensions of the individual well-being (education, life expectancy and GDP per capita) 


\section{CINTIO Export Strategy and Firm Knowledge Acquisition}

equally. In such a case, weighting education more heavily would result in the most optimistic view of human development. Moreover, even though the policymakers aim is to place identical importance to each dimension of welfare by giving the same weight to each indicator, that subindices may receive implicitly a different level of weight because each indicator is obtained through a normalization procedure (Pinar et al., 2017). Under the SD efficiency approach and by adopting a data-driven alternative weighting scheme, Pinar et al. (2015) derive weights that ensure the least volatility over time of Human Development Index in MENA countries. Among the others, Duclos et al. (2006) propose non-parametric SD poverty comparisons using multidimensional attributes of well-being, even though they do not allow for differential weights of each dimension. More recently, taking into account the latest development of multivariate welfare comparisons, Pinar et al. (2020) extend the application of SD from the one-dimensional case to multidimensional poverty analysis in Kenya and Canada. They consider SD efficiency and super-efficiency methodologies that have been used in optimal portfolio construction in finance and show that two relatively similar weighting schemes may produce extremely different multidimensional poverty outcomes.

Recently, also productivity heterogeneity among firms with different level of involvement in international markets has been studied with these non-parametric methods. In particular, the SD approach was introduced into the empirical literature on exports and productivity by Delgado et al. (2002), revealing the superior productivity of Spanish exporters over nonexporters. Similarly, while Girma, et al. (2004) test Irish data, Girma et al. (2005) apply SD techniques for UK manufacturing firms. Both studies show that the productivity distribution of foreign direct investors dominates that of exporters. Analogously, Wagner (2006) presents the first empirical test with German establishment-level data. Elliott and Zhou (2013) adopt conditional SD to examine the impact of firm ownership and trade structure on productivity using a sample of Chinese manufacturing firms. Finally, Fujii et al. (2017) establish a sorting pattern between direct and indirect traders on the basis of the distributions of sales and labor productivity of Japanese firms.

It is worth remarking that, since parametric approaches compare only the first moment of the productivity distribution, they do not provide any information on relative productivity levels elsewhere in the distribution. Thus, traditional regression analysis might give inaccurate conclusions regarding productivity differences across firms. Moreover, traditional parametric method implicitly assumes that only firms with levels of productivity over a critical threshold will export. Differently, non-parametric methods remove the cut-off level for firms to export and instead allow firms with the same level of productivity to choose either to export or not (Elliott and Zhou, 2013). Thus, by analyzing TFP differences across the whole distribution of firms, we are confident that a non-parametric SD approach allows us to provide a robust comparison of productivity between exporters and non-exporters, and among the different categories of exporting firms. However, despite its advantages, SD methods are not exempt 
from limitations. For instance, it does not allow to obtain cardinal results. Therefore, as specifically illustrated in the next section, we evaluate also the impact of the export modes on firms' TFP by estimating a propensity score through a machine learning method.

\subsection{Empirical Methodology}

The K-S test can be constructed in the following way. Let $F$ and $G$ be the Cumulative Density Functions (CDFs) of the TFP of two categories of firms differing in their export strategy. By testing the hypothesis that the distribution $G$ contains smaller values than the distribution $F$, a positive and significant value of the statistic implies that the distribution $F$ lies to the left of $G$. This test statistics was proposed by Kolmogorov (1933) and Smirnov (1939) and, formally, it can be formulated as follows:

$$
H_{0}: F(z)-G(z) \leq 0 \forall \mathrm{z} \in \mathbb{R} \quad \text { versus } \quad H_{1}: F(z)-G(z)>0 \text { for some } \mathrm{z} \in \mathbb{R} \text {. }
$$

where $z$ is the productivity level. Therefore, by detecting first-order SD, the one-tailed test is able to establish which category of firms exhibits a higher level of TFP.

Once differences of productivity among firms are established, we investigate the extent to which firms' participation in treatment $t^{\prime}$ allows for higher or lower TFP with respect to the treatment $t$. Following Lechner 2002, the causal estimand of interest is the ATT $(\tau)$ :

$$
\tau_{t^{\prime}, t}=E\left(Y_{t^{\prime}}-Y_{t} \mid T=t^{\prime}\right)=E\left(Y_{t^{\prime}} \mid T=t^{\prime}\right)-E\left(Y_{t} \mid T=t^{\prime}\right),
$$

where $Y$ is the outcome (i.e. firms' TFP) associated with treatment status $T$, and the possible treatments (i.e. the different export strategies) are $t^{\prime}$ and $t$, respectively, for treated and control units. In other words, the ATT answers the question: "On average, how the outcome would change if who received a specific treatment had instead received another treatment?"

However, since we only observe the outcome of different units under the treatment they actually received, we need a counterfactual outcome for the control units. To do that, we weight observations in the control group $t$ by the ratio of the probabilities of receiving treatment $t^{\prime}$ over treatment $t$, conditional on pre-treatment variables $X$ (i.e. $w_{i}\left[t^{\prime}, t\right]=\hat{p}_{t^{\prime}}\left(X_{i}\right) / \hat{p}_{t}\left(X_{i}\right)$ ). Such probabilities are calculated by estimating the propensity score through a machine learning method which minimizes the average standardized absolute mean difference (or Standardized Bias) for each covariate $k:^{9}$

\footnotetext{
${ }^{9}$ In particular, we refer to the Generalized Boosted Model (GMB). See McCaffrey et al. (2004) for a detailed description.
} 
DI CINTIO Export Strategy and Firm Knowledge Acquisition

$$
S B_{k}=\left|\bar{X}_{k t^{\prime}}-\bar{X}_{k t}\right| / \hat{\sigma}_{k t^{\prime}}
$$

where $\bar{X}_{k}$ is the weighted mean of the covariate for the two treatment levels $t^{\prime}$ and $t$, and $\hat{\sigma}_{k t^{\prime}}$ is the standard deviation of the covariate in the treated group, $t^{\prime}$.

Since the best balance is achieved when each pre-treatment variable does not explain any significant difference between treated and control units, we are able to construct a reliable counterfactual mean for those units (control units) who did not receive the specific treatment under investigation. Specifically, we predict treatment assignments through 3000 iterations and assess the goodness of balance by evaluating the Standardized Bias before and after the weighting. Under weighted statistics and since the Standardized Bias is reduced at the minimum, each covariate is not more significant in explaining differences between control and treated units. Therefore, we are confident that the bias due to differences in pre-treatment characteristics (observable input factors and firms age) is theoretically eliminated. In this way, as different input endowments do not affect the choice of the different export modes, we also correct for potential self-selection.

The estimated propensity score is then applied to estimate the ATT as:

$$
\tau_{t^{\prime}, t}=\frac{1}{N^{t^{\prime}}} \sum_{i \in t^{\prime}} Y_{i, t^{\prime}}-\frac{1}{N^{t^{\prime}}} \sum_{i \in t} w_{i}\left[t^{\prime}, t\right] Y_{i, t}
$$

Thus, estimated ATTs measure how the level of knowledge (the unobservable input factor) would change if firms with a given export strategy had chosen a different one.

We are conscious that some caveats merit to be pointed out. In particular, we acknowledge that firms may self-select into the export markets. Nevertheless, since firms need to achieve an adequate level of absorptive capacity in order to benefit from learning-by exporting effects, we adjust the outcome model by controlling for the already acquired level of knowledge. Thus, Following Bratti and Felice (2012) and Salomon and Myles Shaver (2005), we include among regressors also the lagged value of TFP. In this way, by controlling for the productivity levels before exporting, we are confident that the potential problems of reverse causality should be alleviated.

\section{Results}

In line with what was described in the previous section, we first tested the SD of TFP distributions among different categories of firms. Then, we measure the impact of the export modes on firms' TFP through the estimation of ATTs. 


\subsection{Export Modes and TFP Distributions: The Stochastic Dominance Tests}

We start by comparing the TFP distributions estimated with the Levinsohn and Petrin (2003) methodology. Table 3 shows the results of the K-S tests.

We report the statistics and $p$-values of the one-tailed test to determine which of the two distributions dominates the other. The one-tailed tests did not fail to reject the null hypothesis that the TFP distribution of indirect traders stochastically dominates the distribution of nonexporters. When we performed similar tests to check for the inverted relationship, we failed to reject the null hypothesis of stochastically dominated TFP distributions. Thus, indirect traders incorporate more knowledge than non-exporters (panel $a$ ). A similar scenario emerges when we compare non-exporters with the other categories of exporters (panel $b$ ) and $c$ ). At the same time, panel $d$ ) shows that mixed exporters have higher unobservable productivity than indirect exporters, as well as (panel e) direct exporters versus indirect exporters. Therefore, we confirmed the conclusions of Muûls and Pisu (2009), Lu et al. (2017), Wagner (2017), and Békés and Muraközy (2018), who proved that firms who trade are more productive than nonexporters and, among the former, those who choose to export directly exhibit higher productivity. Moving on the last panel, we did not find a significant difference between the distributions of TFP of mixed and direct exporters. Maybe, it depends on the fact that when firms trade through both modes (direct and indirect), they have already overcome the higher fixed costs of trading directly.

Table 3: Tests of Stochastic Dominance

\begin{tabular}{|c||l||c|c|}
\hline Comparisons: & Smaller group & Distance & P-value \\
\hline \hline \multirow{2}{*}{$(a)$} & Non-Exporters & 0.108 & 0.000 \\
\cline { 2 - 4 } & Indirect Exporters & -0.039 & 0.179 \\
\hline \multirow{2}{*}{$(b)$} & Non-Exporters & 0.307 & 0.000 \\
\cline { 2 - 4 } & Mixed Exporters & -0.010 & 0.910 \\
\hline \multirow{2}{*}{$(c)$} & Non-Exporters & 0.288 & 0.000 \\
\cline { 2 - 4 } & Direct Exporters & -0.006 & 0.885 \\
\hline \multirow{2}{*}{$(d)$} & Indirect Exporters & 0.238 & 0.000 \\
\cline { 2 - 4 } & Mixed Exporters & -0.010 & 0.953 \\
\hline \multirow{2}{*}{$(e)$} & Indirect Exporters & 0.213 & 0.000 \\
\cline { 2 - 4 } & Direct Exporters & -0.006 & 0.965 \\
\hline \multirow{2}{*}{$(f)$} & Mixed Exporters & 0.015 & 0.832 \\
\cline { 2 - 4 } & Direct Exporters & -0.040 & 0.281 \\
\hline
\end{tabular}

Positive and Significant distance means that the group distribution lies on the left of that of the other group 
DI CINTIO Export Strategy and Firm Knowledge Acquisition

A graphical comparison among the TFP distributions (Figure 1) corroborates our results. Moreover, the graphical representations of the cumulative distributions (Figure 2) confirm that the TFP distribution of indirect exporters lies on the left of that of direct exporters.

Figure 1: Kernel Density

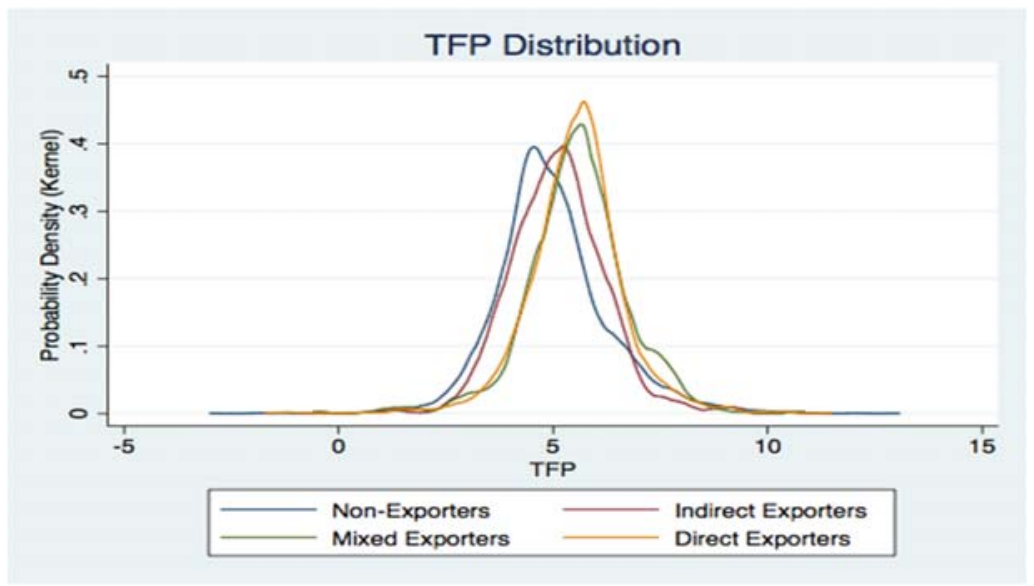

Figure 2: Cumulative Distributions by Export Mode
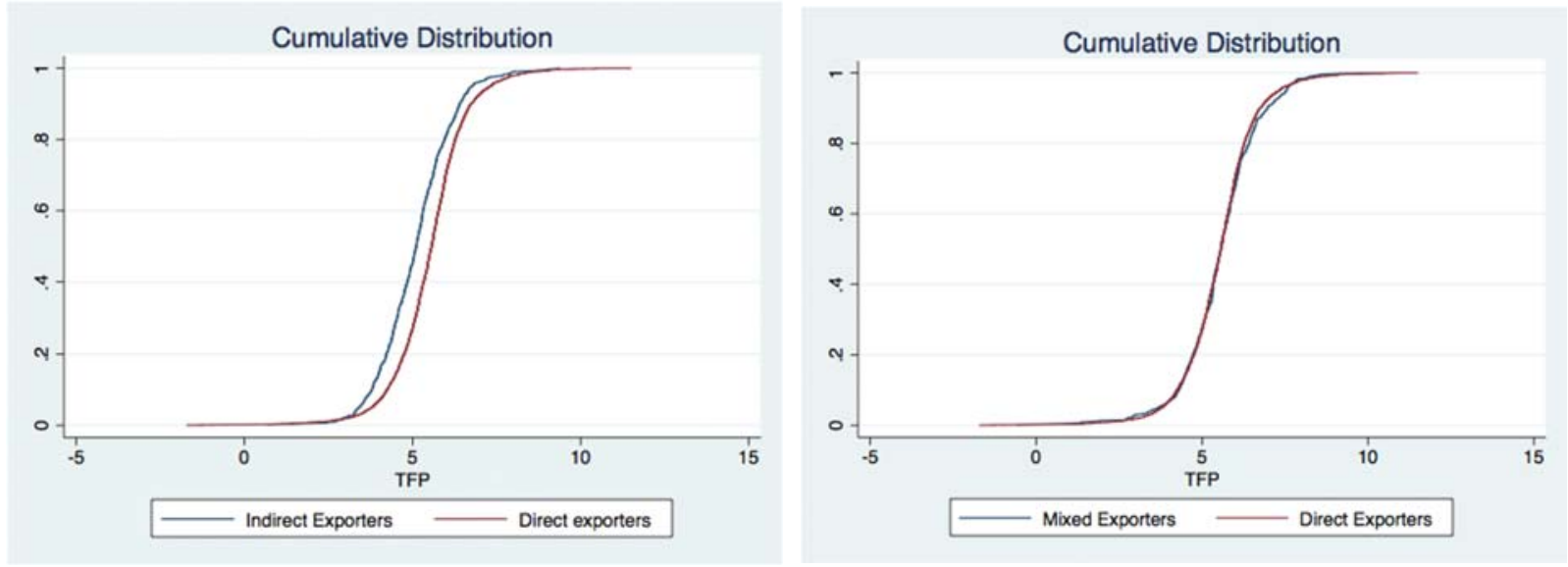

Mixed and direct exporters have similar TFP distributions. Since these last two categories of traders are homogenous in terms of TFP, in what follows we will consider both as one single category of direct exporters. ${ }^{10}$

${ }^{10}$ See McCann (2013) for a similar approach. 
Review of Economic Analysis 12 (2020) 461-483

Table 4: TFP by Export Mode

\begin{tabular}{|c||l|l|c|}
\hline \multicolumn{1}{|c|}{ Export Mode } & \multicolumn{1}{|c|}{ Estimated TFP } & Mean & Std. Dev. \\
\hline \hline \multirow{4}{*}{ Non-exporter firms } & Levinsohn and Petrin (2003) & 4.974 & 1.320 \\
\cline { 2 - 4 } & Wooldridge (2009) & 5.023 & 1.389 \\
\cline { 2 - 4 } & Fixed Effect & 5.458 & 1.382 \\
\hline \multirow{3}{*}{ Indirect Exporters } & Levinsohn and Petrin (2003) & 5.109 & 1.104 \\
\cline { 2 - 4 } & Wooldridge (2009) & 5.069 & 1.127 \\
\cline { 2 - 4 } & Fixed Effect & 5.645 & 1.145 \\
\hline \multirow{3}{*}{ Direct Exporters } & Levinsohn and Petrin (2003) & 5.535 & 1.150 \\
\cline { 2 - 4 } & Wooldridge (2009) & 5.485 & 1.171 \\
\cline { 2 - 4 } & Fixed Effect & 6.137 & 1.193 \\
\hline
\end{tabular}

As a robustness check, we also refer to two alternative TFP estimation methods. Both under the Wooldridge (2009) approach and the fixed-effect estimation, direct exporters exhibit a higher level of TFP, followed, respectively, by indirect exporters and non-exporters. Mixed and direct exporters have similar TFP distributions. Since these last two categories of traders are homogenous in terms of TFP, in what follows we will consider both as one single category of direct exporters.

Table 4 above summarizes the sample averages of firms' TFP by export mode.

\subsection{ATT Results}

The causal effect of the chosen export mode on firms' TFP is the difference between the average performance of firms, given an export mode treatment and a comparable alternative choice. Thus, our ATT quantify how much firms' participation in treatment $t^{\prime}$ increases or reduces their TFP compared to the control group $t .{ }^{11}$ In particular, we estimate the ATT under three models by adjusting the outcome model through the control for different firms' characteristics. Specifically, Model 1 controls for input factors (number of workers and capital stock), firm's age, country and industry fixed effects. Model 2 considers also past TFP as a proxy of firms' absorptive capacity. Finally, Model 3 adds further covariates to account for institutional obstacles faced by firms.

\footnotetext{
${ }^{11}$ We predict treatment assignment by using a machine learning method (i.e. Boosted Regression Method) through 3000 iterations. We find a very strong reduction of the standardized effect size for each pre-treatment variable. The estimated propensity score weights yield an accurate balance of the pre-treatment covariates and all the details are available upon request.
} 


\section{CINTIO Export Strategy and Firm Knowledge Acquisition}

As shown in Table 5, being an indirect exporter or a direct exporter rather than a nonexporter significantly increases the TFP level by $0.096 \%$ and $0.212 \%$, respectively. So, jointly considered, these results confirm the learning-by-exporting hypothesis. So, this hypothesis is still valid also when firms export indirectly. Moreover, the last comparison proves that direct exporters acquire more knowledge than indirect exporters.

Table 5: Average Treatment effect (ATT) - Model 1

\begin{tabular}{|l||l|l|l|l|l|l|}
\hline \multicolumn{1}{|c||}{ Comparisons: } & \multicolumn{2}{c|}{$\begin{array}{c}\text { Indirect Exporters } \\
\text { Vs. Non-exporters }\end{array}$} & \multicolumn{2}{c|}{$\begin{array}{c}\text { Direct Exporters } \\
\text { Vs. Non-exporters }\end{array}$} & \multicolumn{2}{c|}{$\begin{array}{c}\text { Direct Exporters } \\
\text { Vs. Indirect Exporters }\end{array}$} \\
\hline ATT & $0.096^{* *}$ & $(0.043)$ & $0.212^{* * *}$ & $(0.028)$ & $0.184 * * *$ & $(0.047)$ \\
\hline Workers (Log) & $0.144^{* * *}$ & $(0.029)$ & $0.101^{* * *}$ & $(0.020)$ & $0.105^{* * *}$ & $(0.027)$ \\
\hline Capital Stock (Log) & $0.048^{* *}$ & $(0.019)$ & $0.102^{* * *}$ & $(0.015)$ & $0.076^{* * *}$ & $(0.020)$ \\
\hline Firms age & $-0.004^{* * *}$ & $(0.001)$ & $-0.002^{* *}$ & $(0.001)$ & $-0.002^{* *}$ & $(0.001)$ \\
\hline \hline Constant & $3.128^{* * *}$ & $(0.151)$ & $2.647^{* * *}$ & $(0.145)$ & $2.968^{* * *}$ & $(0.279)$ \\
\hline \hline Country FE & Yes & & Yes & & Yes & \\
\hline Industry FE & Yes & & Yes & & Yes & \\
\hline \hline R Squared & 0.382 & & 0.363 & & 0.361 & \\
\hline Observations & 7421 & & 10048 & & 3813 & \\
\hline
\end{tabular}

$* \mathrm{p}<0.10, * * \mathrm{p}<0.05, * * * \mathrm{p}<0.01$ (Standard errors in parentheses)

The knowledge gained by indirect exporters is lower because trade intermediaries do not share important pieces of information (such as destination countries' local demand, product preferences and foreign market conditions) and, thus, act as barriers to international knowledge transfer. This does not happen for direct exporters, whose stock of knowledge turns out to be higher.

\subsection{Chinese and other Asian Firms}

Since China began to open up its economy in the late 1970s, while foreign-owned firms had direct trading rights, many restrictions were applied to domestic owned firms. In particular, the Foreign Trade Law adopted in 1994 formalized the so-called "approval system" of foreign trade rights and, in 1998, the State Council approved the issuing of direct trading rights to private firms whose registered capital, sales, net assets, and exports exceeded specific threshold levels. These thresholds were progressively reduced, and, by July 2004, the Chinese government removed all restrictions on direct trading rights. Therefore, the China case is among the more excellent candidate for our study. 
Specifically, in considering exporting as a potential driver of knowledge acquisition, in what follows, we try to shed light to what extend the learning-by-exporting may explain the larger growth of Chinese firms with respect other Asian firms in the international scenario. Thus, first, we verify whether or not the above results for the whole sample are also valid for a sub-sample of Chinese firms. Second, we provide a comparison between Chinese and other Asian firms in terms of knowledge acquired from abroad by distinguishing among non-exporter firms, indirect exporters and direct exporters.

Table 6 reports the results of Model 2. Also controlling for firms' absorptive capacity, the ATTs remain positive and significant. In particular, we notice that the $R^{2}$ increases substantially in all three comparisons.

The estimates for the ATT in Model 3 (see * $\mathrm{p}<0.10,{ }^{* *} \mathrm{p}<0.05,{ }^{* * *} \mathrm{p}<0.01$ (Standard errors in parentheses)

Table 7) further confirm our previous results. Again, we find positive and significant ATTs in each comparison. As a consequence, first, we argue that exporters are more productive than non-exporters because firms acquire more knowledge as they export, not just because the most productive firms self-select into exporting. Second, our results extend this finding by concluding that the export mode plays a fundamental role in firms knowledge acquisition.

Despite the growing use of trade intermediaries, our estimations are consistent with the evidence from other emerging countries and support the view that direct export promotion efforts might have remarkable effects in terms of firms' productivity improvements.

\subsection{Chinese and other Asian Firms}

Since China began to open up its economy in the late 1970s, while foreign-owned firms had direct trading rights, many restrictions were applied to domestic owned firms. In particular, the Foreign Trade Law adopted in 1994 formalized the so-called "approval system" of foreign trade rights and, in 1998, the State Council approved the issuing of direct trading rights to private firms whose registered capital, sales, net assets, and exports exceeded specific threshold levels. These thresholds were progressively reduced, and, by July 2004, the Chinese government removed all restrictions on direct trading rights. Therefore, the China case is among the more excellent candidate for our study.

Specifically, in considering exporting as a potential driver of knowledge acquisition, in what follows, we try to shed light to what extend the learning-by-exporting may explain the larger growth of Chinese firms with respect other Asian firms in the international scenario. Thus, first, we verify whether or not the above results for the whole sample are also valid for a sub-sample of Chinese firms. Second, we provide a comparison between Chinese and other Asian firms in 
DI CINTIO Export Strategy and Firm Knowledge Acquisition

terms of knowledge acquired from abroad by distinguishing among non-exporter firms, indirect exporters and direct exporters.

Table 6: Average Treatment effect (ATT) - Model 2

\begin{tabular}{|c|c|c|c|c|c|c|}
\hline Comparisons: & $\begin{array}{l}\text { Indirect } \\
\text { Vs. Non- }\end{array}$ & $\begin{array}{l}\text { orters } \\
\text { orters }\end{array}$ & $\begin{array}{l}\text { Direct E } \\
\text { Vs. Non- }\end{array}$ & $\begin{array}{l}\text { orters } \\
\text { porters }\end{array}$ & $\begin{array}{l}\text { Direct } \\
\text { Vs. Indir }\end{array}$ & $\begin{array}{l}\text { xporters } \\
\text { Exporters }\end{array}$ \\
\hline ATT & $0.061 *$ & $(0.033)$ & $0.088 * * *$ & $(0.016)$ & $0.074 * *$ & $(0.030)$ \\
\hline Workers (Log) & $0.032 * *$ & $(0.013)$ & 0.003 & $(0.013)$ & $0.029 * *$ & $(0.014)$ \\
\hline Capital Stock (Log) & -0.007 & $(0.008)$ & $0.024 * *$ & $(0.011)$ & -0.001 & $(0.011)$ \\
\hline Firms age & $-0.002 * * *$ & $(0.001)$ & $-0.001 * *$ & $(0.000)$ & $-0.001^{*}$ & $(0.001)$ \\
\hline Absorptive Capacity & $0.811^{* * *}$ & $(0.043)$ & $0.792 * * *$ & $(0.027)$ & $0.773 * * *$ & $(0.044)$ \\
\hline Constant & $0.825 * * *$ & $(0.180)$ & $0.750 * * *$ & $(0.201)$ & $0.897 * * *$ & $(0.170)$ \\
\hline Country FE & Yes & & Yes & & Yes & \\
\hline Industry FE & Yes & & Yes & & Yes & \\
\hline R Squared & 0.803 & & 0.794 & & 0.797 & \\
\hline Observations & 4873 & & 6651 & & 2610 & \\
\hline
\end{tabular}

$* \mathrm{p}<0.10, * * \mathrm{p}<0.05, * * * \mathrm{p}<0.01$ (Standard errors in parentheses)

Table 7: Average Treatment effect (ATT) - Model 3

\begin{tabular}{|l||l|l|l|l|l|l|}
\hline \multicolumn{1}{|c||}{ Comparisons: } & \multicolumn{2}{c|}{$\begin{array}{l}\text { Indirect Exporters } \\
\text { Vs. Non-exporters }\end{array}$} & \multicolumn{2}{c|}{ Direct Exporters } & \multicolumn{2}{c|}{$\begin{array}{c}\text { Direct Exporters } \\
\text { Vs. Indirect Exporters }\end{array}$} \\
\hline \hline ATT & $0.074^{* *}$ & $(0.036)$ & $0.090^{* * *}$ & $(0.018)$ & $0.060^{* *}$ & $(0.029)$ \\
\hline Workers (Log) & $0.043^{* * *}$ & $(0.014)$ & 0.004 & $(0.015)$ & $0.027^{*}$ & $(0.015)$ \\
\hline Capital Stock (Log) & -0.007 & $(0.009)$ & $0.023^{*}$ & $(0.012)$ & 0.001 & $(0.012)$ \\
\hline Firms age & $-0.002^{* *}$ & $(0.001)$ & $-0.001 * *$ & $(0.000)$ & $-0.002^{* *}$ & $(0.001)$ \\
\hline Absorptive Capacity & $0.782^{* * *}$ & $(0.048)$ & $0.777^{* * *}$ & $(0.030)$ & $0.760^{* * *}$ & $(0.046)$ \\
\hline Trade Regulation Obstacles & 0.041 & $(0.031)$ & 0.016 & $(0.020)$ & 0.030 & $(0.030)$ \\
\hline Financial Constraint & 0.009 & $(0.048)$ & -0.029 & $(0.022)$ & 0.003 & $(0.043)$ \\
\hline Financial Cost & $-0.098^{*}$ & $(0.051)$ & 0.007 & $(0.023)$ & $-0.149^{* * *}$ & $(0.049)$ \\
\hline Macroeconomic Obstacles & 0.001 & $(0.032)$ & -0.026 & $(0.019)$ & 0.007 & $(0.038)$ \\
\hline
\end{tabular}


Review of Economic Analysis 12 (2020) 461-483

\begin{tabular}{|l||l|l|l|l|l|l|}
\hline Legal System Obstacles & 0.015 & $(0.028)$ & 0.015 & $(0.029)$ & 0.031 & $(0.032)$ \\
\hline Workers Educational Obstacles & -0.017 & $(0.030)$ & -0.029 & $(0.019)$ & -0.054 & $(0.033)$ \\
\hline \hline Constant & $0.932 * * *$ & $(0.203)$ & $0.836^{* * *}$ & $(0.209)$ & $0.955^{* * *}$ & $(0.166)$ \\
\hline \hline Country FE & Yes & & Yes & & Yes & \\
\hline Industry FE & Yes & & Yes & & Yes & \\
\hline \hline R Squared & 0.801 & & 0.777 & & 0.801 & \\
\hline Observations & 3577 & & 5249 & & 2404 & \\
\hline
\end{tabular}

$* \mathrm{p}<0.10, * * \mathrm{p}<0.05, * * * \mathrm{p}<0.01$ (Standard errors in parentheses)

As for the whole sample, we evaluate the different export strategies in terms of output (sales) and observable input factors (number of workers and level of capital). For each of these indicators, direct exporters have, on average, the highest mean value, followed by indirect exporters and non-exporters (Table 8 - panel $a$ ). Moving on panel $b$, Table 8 shows that the TFP distribution of direct exporters stochastically dominates that of indirect exporters and that the distribution of both categories of exporters dominates that of non-exporters. As a consequence, the estimated TFP - on average - is higher for direct exporters, followed by indirect exporters and non-exporters (Table 8 - panel c).

Thus, results for Chinese firms, again, are in line with the existing literature on the learningby-exporting hypothesis. But, what about the comparison between Chinese and other Asian Firms? For a given export strategy - Chinese firms acquire more or less knowledge than other Asian firms? To answer this question, we use a SD approach.

Table 8: Chinese Firms and Export Modes

\begin{tabular}{|c|c|c|c|c|c|c|c|c|c|c|}
\hline \multicolumn{4}{|c|}{$\begin{array}{l}\text { Output and Input factors } \\
\text { by Export Mode }\end{array}$} & \multicolumn{3}{|c|}{$\begin{array}{l}\text { Test of Stochastic Dominance } \\
\text { (Kolmogorov-Smirnov) }\end{array}$} & \multicolumn{4}{|c|}{$\begin{array}{c}\text { TFP } \\
\text { by Export Mode }\end{array}$} \\
\hline $\begin{array}{l}\text { Export } \\
\text { Mode }\end{array}$ & $\begin{array}{c}\text { Variable } \\
\text { (logs) }\end{array}$ & "Mean & $\begin{array}{l}\text { Std. } \\
\text { Dev. }\end{array}$ & $\begin{array}{l}\text { Smaller } \\
\text { group }\end{array}$ & Distance & P-value & $\begin{array}{l}\text { Export } \\
\text { Mode }\end{array}$ & $\overline{~ E s t i m a t e d ~ T F P ~}$ & "Mean & $\begin{array}{l}\text { Std } \\
\text { Dev. }\end{array}$ \\
\hline \multirow{3}{*}{$\begin{array}{l}\text { Non- } \\
\text { exporter }\end{array}$} & Sales & 11.780 & 1.896 & $\begin{array}{l}\text { Non- } \\
\text { Exporters }\end{array}$ & 0.212 & 0.001 & \multirow{3}{*}{$\begin{array}{l}\text { Non- } \\
\text { exporter }\end{array}$} & $\begin{array}{l}\text { Levinsohn and } \\
\text { Petrin (2003) }\end{array}$ & 4.860 & 1.143 \\
\hline & Workers & 5.026 & 1.427 & $\begin{array}{l}\text { Indirect } \\
\text { Exporters }\end{array}$ & -0.063 & 0.525 & & Wooldridge (2009) & 4.764 & 1.154 \\
\hline & Capital & 11.608 & 2.278 & & & & & Fixed Effect & 5.450 & 1.145 \\
\hline \multirow{3}{*}{$\begin{array}{l}\text { Indirect } \\
\text { Exporters }\end{array}$} & Sales & 12.763 & 1.942 & $\begin{array}{l}\text { Non- } \\
\text { Exporters }\end{array}$ & 0.312 & 0.000 & \multirow{3}{*}{$\begin{array}{l}\text { Indirect } \\
\text { Exporters }\end{array}$} & $\begin{array}{l}\text { Levinsohn and } \\
\text { Petrin (2003) }\end{array}$ & 5.201 & 0.979 \\
\hline & Workers & 5.702 & 1.359 & $\begin{array}{l}\text { Direct } \\
\text { Exporters }\end{array}$ & -0.019 & 0.912 & & Wooldridge (2009) & 5.066 & 0.991 \\
\hline & Capital & 12.630 & 2.270 & & & & & Fixed Effect & 5.853 & 0.993 \\
\hline $\begin{array}{c}\text { Direct } \\
\text { Exporters }\end{array}$ & Sales & 13.679 & 1.802 & $\begin{array}{l}\text { Indirect } \\
\text { Exporters }\end{array}$ & 0.238 & 0.000 & $\begin{array}{c}\text { Direct } \\
\text { Exporters }\end{array}$ & $\begin{array}{l}\text { Levinsohn and } \\
\text { Petrin (2003) }\end{array}$ & 5.511 & 1.147 \\
\hline
\end{tabular}


DI CINTIO Export Strategy and Firm Knowledge Acquisition

\begin{tabular}{|l|l|l|l||l|l|l||l|l|l|l|}
\hline \multirow{2}{*}{} & Workers & 6.077 & 1.462 & $\begin{array}{l}\text { Direct } \\
\text { Exporters }\end{array}$ & -0.017 & 0.938 & & Wooldridge (2009) & 5.380 & 1.157 \\
\cline { 2 - 5 } & Capital & 13.382 & 1.995 & & & & Fixed Effect & 6.194 & 1.144 \\
\hline
\end{tabular}

Table 9: Tests of Stochastic Dominance - Chinese Vs. other Asian Firms

\begin{tabular}{|c||l|l|l|}
\hline \multicolumn{1}{|c|}{ Export Mode } & \multicolumn{1}{|c|}{ Smaller group } & Distance & P-value \\
\hline \hline \multirow{2}{*}{ Non-exporter } & other Asian Firms & 0.067 & 0.071 \\
\cline { 2 - 4 } & Chinese Firms & -0.117 & 0.000 \\
\hline \multirow{2}{*}{ Indirect Exporters } & other Asian Firms & 0.273 & 0.000 \\
\cline { 2 - 4 } & Chinese Firms & -0.008 & 0.993 \\
\hline \multirow{2}{*}{ Direct Exporters } & other Asian Firms & 0.123 & 0.024 \\
\cline { 2 - 4 } & Chinese Firms & -0.023 & 0.883 \\
\hline
\end{tabular}

In Table 9, above, for a given export mode (first column), we perform the K-S test to verify whether or not the TFP distribution of Chinese firms dominates that of the other Asian firms. Specifically, while we are not able to establish a first order SD among non-exporters, results clearly show that Chinese exporters (both direct and indirect) outperform other Asian firms in terms of acquired knowledge.

The graphical representation of the cumulative distributions (Figure 3) confirms a higher level of TFPs exhibited by Chinese exporters.
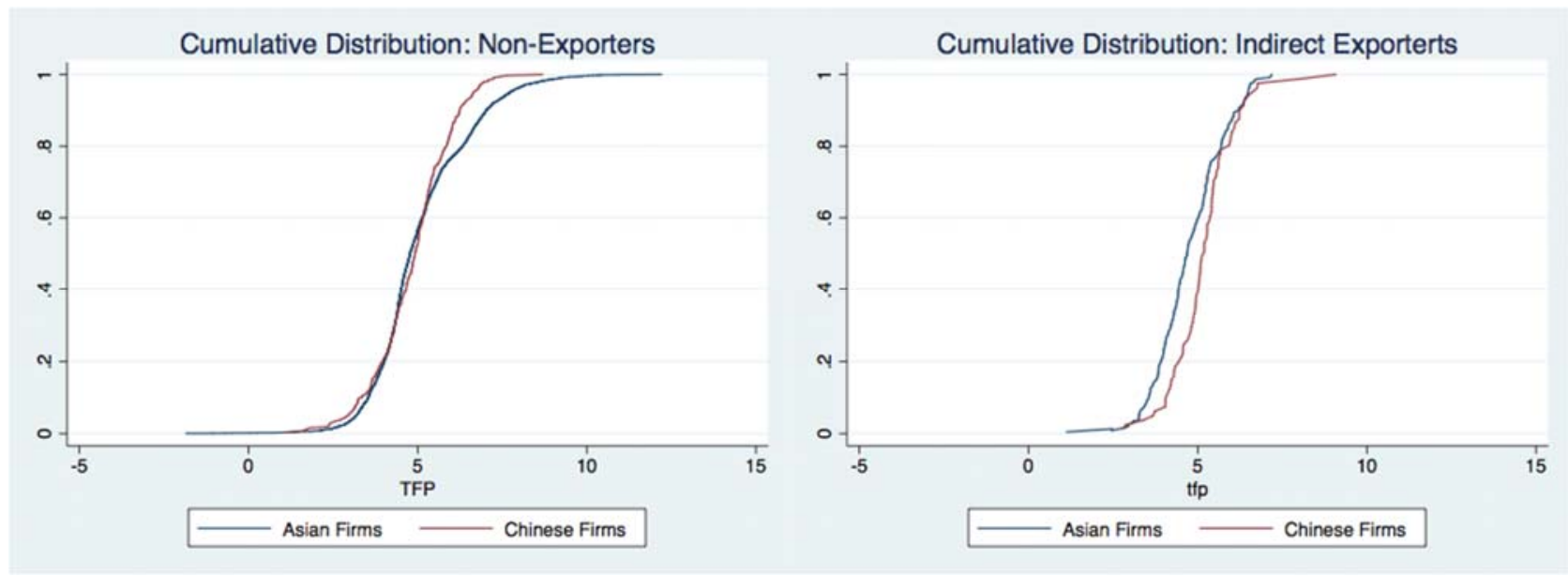

Figure 3: Cumulative Distribution by Export Mode - Chinese Vs. other Asian Firms 


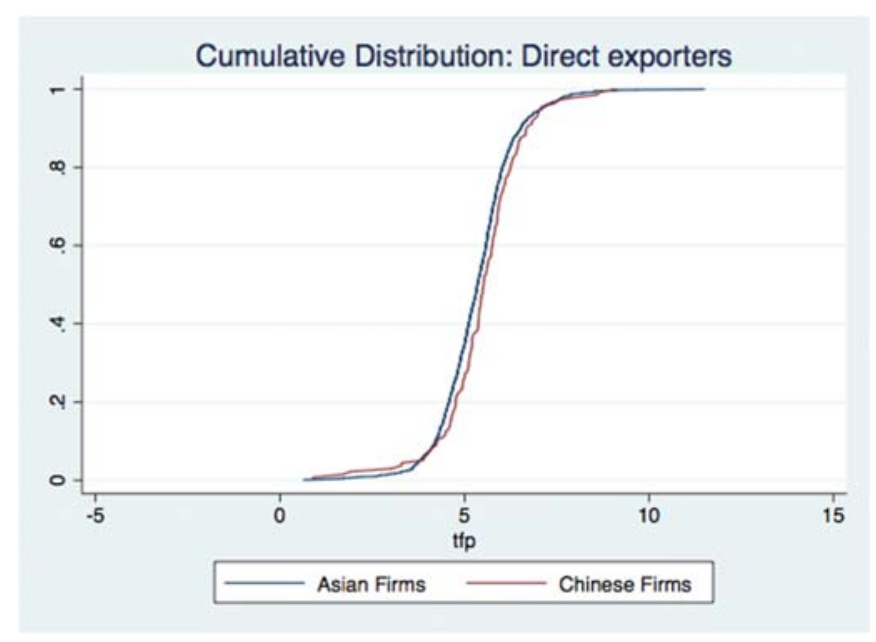

\section{Conclusions}

Since the rise of emerging economies in the global scenario, it has been critical to better understand the role of knowledge. While there is a strong theoretical and empirical support for the hypothesis of self-selection into exporting, theories and pieces of evidence in favour of learning by exporting are quite scarce, especially in presence of export intermediaries.

Thus, we study whether different export strategies may generate a different level of knowledge acquisition. In particular, the study was based on the Data of the World Bank Enterprise Surveys, and we focused on 25 emerging economies. Specifically, our research mainly asked three research questions:

I. Is the learning by exporting hypothesis still valid when firms export indirectly?

II. Do direct exporters acquire more knowledge than indirect exporters?

III. What about the comparison between Chinese and other Asian firms?

Hence, first, we test the learning by exporting hypothesis through a first order stochastic dominance approach. Then, we evaluate the effects of different export modes on the level of knowledge acquired by firms. In particular, through a machine learning method, we evaluate how the level of knowledge acquired by firms would change if those who choose a specific strategy had instead chosen another one. Our results show that (1) the learning by exporting hypothesis is still valid when firms indirectly export; (2) direct exporters acquire more knowledge than indirect exporters; (3) under the same export strategy, Chinese exporters (direct and indirect) acquire more knowledge than other Asian exporters.

The policy implications we wish to emphasize from our results are straightforward. First, learning-by-exporting is considerably different across export modes. For this reason, policies 


\section{CINTIO Export Strategy and Firm Knowledge Acquisition}

that encourage direct exporting might be worth considering. Moreover, our results also permit to evaluate positively the choice of the Chinese government to remove all restrictions on the direct trading rights, since it had a significant effect in fostering international knowledge transfer and on promoting Chinese export growth.

\section{References}

Abel-Koch, J. 2011. Firm Size and the Choice of Export Mode , Discussion Paper 1105 (Mainz: Gutenberg School of Management and Economics).

Abel-Koch, J. 2013. Who Uses Intermediaries in International Trade? Evidence from FirmLevel Survey Data. The World Economy 36 (8): 1041-1064. doi:10.1111/twec.12025.

Antràs, P. \& Costinot, A. 2010. Intermediation and Economic Integration. American Economic Review 2: 424-428. doi:10.1257/aer.100.2.424.

Asplund, M. 2002. Risk-averse firms in oligopoly. International Journal of Industrial Organization 20(7): 995-1012. doi:10.1016/s0167-7187(01)00070-4

Atkinson, A.B. 1987. On the measurement of poverty. Econometrica 55(4): 749-764.

Barrett, G. F., \& Donald, S. G. 2003. Consistent tests for stochastic dominance. Econometrica 71(1): 71- 104.

Békés, G. \& Muraközy, B. 2018. The ladder of internationalization modes: evidence from European firms. Review of World Economics, 83(6), 1-37.

Bernard, A. B. \& Wagner, J. 2001. Export entry and exit by German firms. Review of World Economics, 137, 105-123.

Bernard, A. B., Grazzi, M. \& Tomasi, C. 2015. Intermediaries in International Trade: Products and Destinations. Review of Economics and Statistics 97 (4): 916-920. doi:10.1162/REST_a_00495.

Bratti, M. \& Felice, G. 2012. Are Exporters More Likely to Introduce Product Innovations? The World Economy 35 (11): 1559-1598. doi:10.1111/twec.2012.35.issue-11.

Damijan, J. P., Kostevc, Č. \& Polanec, S. 2010. From Innovation to Exporting or Vice Versa? The World Economy 33 (3): 374-398. doi:10.1111/j.1467-9701.2010.01260.x.

Delgado, M. A., Farinas, J. C. \& Ruano S. 2002. Firms' productivity and ex-port markets: A non-parametric approach. Journal of International Economics 57(2): 397-422.

De Loecker, J. 2013. Detecting Learning by Exporting. American Economic Journal: Microeconomics 5 (3): 1-21.

Di Cintio, M., Ghosh, S. \& Grassi, E. 2020. Direct or indirect exports: what matters for firms' innovation activities? Applied Economics Letters 27(2): 93-103. doi: 10.1080/13504851.2019.1610693.

Duclos, J.-Y., Sahn, D. E. \& Younger, S. D. 2006. Robust multidimensional poverty comparisons. Economic Journal 116(514): 943-968. 
Elliott, R. \& Zhou, Y. 2013. State-owned Enterprises, Exporting and Productivity in China: A Stochastic Dominance Approach. World Economy 36: 1000-1028. doi:10.1111/twec.12078

Feenstra, R. C. \& Hanson, G. H. 2004. Intermediaries in Entrepôt Trade: Hong Kong Reexports of Chinese Goods. Journal of Economics \& Management Strategy, 13, 1, 3-35.

Fujii D., Ono Y., Saito Y. U. 2017. Indirect exports and wholesalers: Evidence from interfirm transaction network data. Japan and the World Economy 44: 35-47. https://doi.org/10.1016/j.japwor.2017.11.001.

Girma, S., Görg, H. \& Strobl, E. 2004. Exports, International Investment, and Plant Performance: Evidence from a Non-Parametric Test. Economics Letters 83 (3): 317-324.

Girma, S., Kneller, R. \& Pisu M. 2005. Exports versus FDI: An Empirical Test. Review of World Economy 141: 193-218. https://doi.org/10.1007/s10290-005-0025-9

Golovko, E. \& Valentini, G. 2014. Selective Learning-by- Exporting: Firm Size and Product versus Process Innovation. Global Strategy Journal 4 (3): 161-180. doi:10.1002/gsj.1080.

Gonzalo, J. \& Olmo, J. 2014. Conditional Stochastic Dominance Tests in Dynamic Settings. International Economic Review 55(3): 819-838. doi:10.1111/iere.12072

Greenaway, D. \& Kneller, R. 2007. Firm Heterogeneity, Exporting and Foreign Direct Investment. The Economic Journal 117 (1996): F134-61. doi:10.1111/j.14680297.2007.02018.x.

Haidar, J. I. 2012. Trade and productivity: Self-selection or learning-by-exporting in India. Economic Modelling, 29 (5): 1766-1773.

Hanoch, G. \& Levy, H. 1969. Efficiency analysis of choices involving risk. Review of Economic Studies 36(3): 335-46.

Kolmogorov, A. N. 1933. Sulla determinazione empirica di una legge di distribuzione. Giornale dell' Istituto Italiano degli Attuari 4: 83-91.

Kuosmanen, T. 2004. Efficient Diversification According to Stochastic Dominance Criteria. Management Science 50: 1390-1406.

Lachenmaier, S. \& Wößmann, L. 2006. Does Innovation Cause Exports? Evidence from Exogenous Innovation Impulses and Obstacles Using German Micro Data. Oxford Economic Papers 58 (2): 317-350. doi:10.1093/oep/gpi043.

Lechner, M. 2002. Some Practical Issues in the Evaluation of Heterogeneous Labour Market Programmes by Matching Methods. Journal of the Royal Statistical Society. Series A: Statistics in Society 165 (1): 59-82. doi:10.1111/1467-985X.0asp2.

Lee, J.B., Lacewell R.D. \& Ellis J.R. 1987. Evaluation of Production and Financial Risk: A Stochastic Dominance Approach. Canadian Journal of Agricultural Economics 35: 109126.

Lehmann, E.L. 1955. Ordered families of distributions. The Annals of Mathematical Statistics 26(3): 399-419. 
Leland, H.E. 1972. Theory of the firm facing uncertain demand. The American Economic Review 62(3): 278-291.

Levinsohn, J. \& Petrin, A. 2003. Estimating production functions using inputs to control for unobservables. Review of Economic Studies, 70(2), 317-42.

Linton, O., Maasoumi, E. \& Whang, Y.-J. 2005. Consistent testing for stochastic dominance under general sampling schemes. Review of Economic Studies 72(3): 735-765.

Lu, J., Lu, Y., Sun, Y. \& Tao, Z. 2017. Intermediaries, firm heterogeneity and exporting behaviour. The World Economy, 40(7), 1381-1404.

Luo, Y. 2020. Unobserved heterogeneity in auctions under restricted stochastic dominance. Journal of Econometrics 216(2): 354-374. https://doi.org/10.1016/j.jeconom.2019.07.009.

McCaffrey, D. F., Ridgeway, G. \& Morral, A. R. 2004. Propensity Score Estimation with Boosted Regression for Evaluating Causal Effects in Observational Studies. Psychological Methods 9 (4): 403-425. doi:10.1037/1082- 989X.9.4.403.

McCann, F. 2013. Indirect Exporters. Journal of Industry, Competition and Trade 13: 519 535. doi:10.1007/s10842- 012-0133-x.

Melitz, M. J. 2003. The Impact of Trade on Intra-Industry Reallocations and Aggregate Industry Productivity. Econometrica 71 (6): 1695-1725. doi:10.1111/1468- 0262.00467.

Muûls, M. \& Pisu, M. 2009. Imports and exports at the level of the firm: Evidence from Belgium. World Economy, 32(5), 692-734.

Olabisi, M. 2017. The Impact of Exporting and Foreign Direct Investment on Product Innovation: Evidence From Chinese Manufacturers. Contemp Econ Policy, 35: 735-750. doi:10.1111/coep.12227

Olley, G. S. \& Pakes, A. (1996). The dynamics of productivity in the telecommunications equipment industry, Econometrica, 64(6), 1263-1297.

Pinar, M., Stengos, T. \& Topaloglou, N. 2013. Measuring human development: a stochastic dominance approach. Journal of Economic Growth 18: 69-108. https://doi.org/10.1007/s10887-012-9083-8

Pinar, M., Stengos, T. \& Yazgan, M. E. 2015. Measuring Human Development in the MENA Region. Emerging Markets Finance and Trade 51(6): 11791192. doi:10.1080/1540496x.2015.1080517

Pinar, M., Stengos, T. \& Topaloglou, N. 2017. Testing for the implicit weights of the dimensions of the Human Development Index using stochastic dominance. Economics Letters 161: 38-42. doi:10.1016/j.econlet.2017.09.023

Pinar, M., Stengos, T. \& Topaloglou, N. 2020. On the construction of a feasible range of multidimensional poverty under benchmark weight uncertainty. European Journal of Operational Research. 281(2): 415-427. https://doi.org/10.1016/j.ejor.2019.08.047

Post, T. 2003. Empirical Tests for Stochastic Dominance Efficiency. Journal of Finance 58: 1905-1031. 
Salomon, R. M. \& Shaver, J. M. 2005. Learning by Exporting: New Insights from Examining Firm Innovation. Journal of Economics \& Management Strategy 14 (2): 431-460. doi:10.1111/j.1530-9134.2005.00047.x.

Scaillet, O., \& Topaloglou, N. 2010. Testing for stochastic dominance efficiency. Journal of Business and Economic Statistics 28(1): 169-180.

Schott, P. K. 2008. The Relative Sophistication of Chinese Exports. Economic Policy, 23(53), 5- 49.

Stinnett A.A. \& Mullahy J. 1998. Net health benefits: a new framework for the analysis of uncertainty in cost-effectiveness analysis. Medicine Decision Making 18(2 Suppl): S68-80. doi: 10.1177/0272989X98018002S09

Smirnov, N.V. 1939. On the estimation of the discrepancy between empirical curves of distribution for two independent samples. Bull. Math. Univ. Moscow 2: 3-14.

Wagner J. 2006. Exports, foreign direct investment, and productivity: evidence from German firm level data. Applied Economics Letters 13(6): 347-349. doi:10.1080/13504850500393667

Wagner, J. 2007. Exports and productivity: a survey of the evidence from firm-level data. The World Economy, 30, 60-82.

Wagner, J. 2017. Productivity premia for many modes of internationalization. A replication study of Békés and Muraközy. International Journal for Re-Views in Empirical Economics, $1(4), 1-6$.

Wooldridge, J. M. 2009. On estimating firm-level production functions using proxy variables to control for unobservables. Economics Letters 104: 112-114 